\title{
Una lectura de la trilogía rural de Federico García Lorca (1)
}

José Megias Aznar

Aunque la trayectoria inicial de Lorca es evidentemente de un poeta lírico y una gran parte de su fama se debe a su poesía, no obstante, paralela al desarrollo de su ingente producción lírica, corrió una obra dramática, considerada por muchos autores (entre ellos por su compañero de "generación" Pedro Salinas) como la más importante del nuevo teatro, auténticamente poético, español. Bodas de sangre, Yerma y La casa de'Bernalda Alba, por ceñirnos al objeto de nuestro trabajo, son discursos literarios que definen a la perfección a un poeta dramático plenamente formado, como es su autor.

$Y$ hemos dicho que define a un "poeta dramático", y con ello queremos afirmar que lo lírico y lo dramático no son entidades separadas en Lorca. Aunque es indudable que por un lado están sus obras dramáticas y por otro sus obras líricas, todas ellas responden a la relación arte/vida, es decir a la transcripción artística de la misma vida, "pues -como dice el propio Lorca - no cree en el arte por el arte".

Lo dramático en Lorca no se cine única y exclusivamente a sus obras teatrales en sentido estricto, sino que en sus formas líricas se siente un substrato dramático.

¿Cómo es el dramatismo de Lorca? Es ante todo, popular y tradicional, es un espejo en el que se refleja el concepto vital y de destino de un modo de ver la vida muy andaluza, pero trascendiendo el localismo al igual que la tragedia griega. Su dramatismo es la recreación de los conflictos humanos, determinados por una estructura social, no mecánica, sino a través de "los efectos objetivos y significativos por tales estructuras" (1).

Por un lado aparecerá lo dramático cotidiano, será un dramatismo individual, circunstancial, apasionado y de consecuencias destructoras. Por otro lado aparecerá el dramatismo esencial y genérico como médula de la obra lorquiana.

El dramatismo vital del pueblo andaluz será escenificado magistralmente por García Lorca, que espoleará sus obras con raíces sobrenaturales, deter-

(1) PER US, Françoise: Literatura y sociedad en América Latina: el Modernismo, Habana, Casa de las Américas, 1976. 
ministas y misteriosas. Todas sus obras estarán orientadas a un "leiv motiv": el sino fatal del hombre.

Las obras teatrales de Lorca son populares, en tanto en cuanto los cuadros, el pueblo y los personajes lo son, pero ésto no basta para llamar a una obra "popular"; tampoco es suficiente remitirnos a su temática marcadamente popular, si Bodas de sangre, Yerma y La Casa de Bernalda Alba, son populares es porque materializan y dan categoría de arte a un concepto de vida hecho a lo largo del tiempo en lo más íntimo del pueblo, tradicionalmente conservado y vivo en él, nos estamos refiriendo a la fatalidad humana, al sino, al destino, conceptos que trataremos detenidamente en nuestro estudio de la trilogía de tema rural de nuestro universal autor.

La gran virtud de García Lorca fue dar formas de perennidad a lo popular, poniendo al servicio de la encarnación popular todas las potencias de su gran arte literario. Pues como el dice: "Mi arte no es popular. Yo nunca he considerado que lo sea" (2).

Aunque los personajes de Lorca hablarán con palabras y sentencias corrientes y populares, no por ello su obra es vulgar o rústica. Como dice Salinas, en Lorca puede apreciarse con claridad la fusión de dos valores: "la autenticidad de un lenguaje que en su vocabulario, sus giros e imágenes trasciende a cada instante a lenguaje hablado ayer $y$ hoy por innumerables gentes, lenguaje de un hoy determinado y de una tierra desconocida, y la dignidad literaria, la tensión clásica de lenguaje no perecedero, salvado de las amenazas de lo circunstancial, que exhala esta prosa dramática, de un cuño tan inconfundible en el teatro español de hoy" (3).

La gran potenciación poética de Lorca, va convirtiendo las palabras usuales en hablar de perennidad. Con Lorca estamos ante una de las más vivas formas de la prosa dramática española. Con respecto a la función social del artista y su entorno "habría que aclarar que éste no puede enajenarse de las ideologías dominantes en su época, ni de los condicionamientos de su clase, ya que toda obra literaria funciona, respecto a los valores ideológicos dominantes, como una crítica que revela la visión del mundo del autor. Aunque ninguna obra puede explicarse por la biografía del autor ni el medio social en que éste ha vivido, es esencial identificar la ideología del autor y su sector clasista, ya que esta ideología, como sistema articulado del mundo, incide en su obra. La subjetividad del autor real importa no como algo abstracto $o$ independiente de la vida social, sino como producto histórico que responde a unos valores ideológicos concretos" (4).

(2) GARCIA LORCA, Federico: Obras Completas, Madrid, Aguilar, 16. a , 1971, pág. 1.732 (La referencia numérica en todo el artículo corresponderá a esta edición). 197.

(3) SALINAS, Pedro: Literatura Española. Siglo XX, Madrid, Alianza Editorial, 1970, pág.

(4) ORTEGA, José: Conciencia social en los tres dramas nurales de García Lonca, Granada. Universidad, 1981, pág. 9, 10. 


\section{TRADICION DRAMATICA EN LORCA}

Lorca, en lo referente a sus dramas rurales participa de una tradición dramática anterior, presente ya en Benavente prócer de la "generación" del 98, anterior a la del 27 en que se enmarca nuestro escritor, y que en obras como La Malquerida, toma personajes y situaciones más o menos rurales para dar lugar a su obra.

Pero no es Benavente el primer autor español que trata el tema de lo rural, sino que incluso dentro de nuestro "siglo de oro" autores como Lope de Vega, Calderón y Tirso, auténtico triunvirato representante del teatro español del XVI, tratan profusamente el tema. Y no será difícil encontrar en García Lorca una base temática que se asiente en esta época. Así el triángulo amoroso tratado por Lope será recogido por Lorca, que le aportará sus singulares características dramáticas, y otro tanto puede decirse de las canciones populares tomadas como excusa para narrar un incidente cualquiera de la obra, y que en Fuenteovejuna aparece lo mismo que en la trilogía de García Lorca. Además de Lope, Tirso y Calderón también participan de la temática del triángulo amoroso en obras como La Dama del Olivar y El Alcalde de Zalamea, respectivamente.

Así, pues, Lorca repite la temática amorosa (triángulo clásico) de honor y la canción popular como recurso dramático, al igual que nuestros autores del Siglo de Oro.

Es evidente que Lorca fue un buen conocedor del teatro del Siglo de Oro, no sólo por sus estudios personales, sino por su activísima colaboración con la agrupación teatral La Barraca que le hizo entrar en contacto con numerosas obras de nuestros clásicos. No obstante, no es menos evidente que Lorca aportó elementos nuevos al teatro espaniol, y sus innovaciones en el tratamiento del tema rural al que nos estamos cifiendo, intentaremos recopilarlas siquiera someramente a lo largo del trabajo.

Pero estábamos buscando las raíces del drama rural lorquiano, y antes hemos mencionado a Benavente como posible fuente influenciadora del autor de Fuente Vaqueros, y efectivamente Don Jacinto, verdadero "pater conscripti" de nuestro teatro pudo proporcionar a Federico abundante material en lo que se refiere a dramas rurales, basta con mencionar la ya citada Malquerida y la quizá menos conocida Señora ama para darnos cuenta que Benavente enclava estas obras en un ambiente rural de costumbres tradicionales, lenguaje popular, etc.

Pero con todo lo dicho hasta ahora parece como si quisiéramos considerar a Lorca como un dramaturgo falto de originalidad en la temática y que hubiese sido un mero repetidor de situaciones ya tratadas anteriormente, y nada más lejos de nuestro ánimo. Lorca pese a participar de las tradiciones teatrales españolas es un auténtico dramaturgo original e innovador de nuestro teatro del siglo $\mathrm{XX}$, más de lo que en principio pudiese parecer por lo poco estudiado al respecto, tendríamos que recurrir entonces a la "leyenda 
negra" de Lorca, considerado en España durante el régimen franquista como un escritor maldito, etc. Pero no es esa nuestra tarea. A pesar de todos los pesares, a pesar de todos los olvidos la figura de Lorca -dramaturgo está ahí, considerada tan importante (y para algunos autores más aún) como la imagen del Lorca - poeta.

Así, pues, Lorca imbuido indudablemente de tradición dramática española como han apuntado autores como M. ${ }^{\mathrm{a}}$ Teresa Babin (El Mundo poético de García Lorca) (5), no por ello dejó de enriquecer esa tradición con nuevos elementos, basados muchos de ellos en el mayor cosmopolitismo de nuestro escritor a la cerrazón más o menos aparente de nuestro Siglo de Oro cara al exterior.

La ya citada M. ${ }^{\text {a }}$ Teresa Babin ha presentado similitud de temperamentos entre Unamuno y Lorca, igualmente podemos decir del binomio Inclán-Lorca según la misma autora, que ha querido ver en obras como El amor de don Perlimplin, lorquiano paralelismo con los esperpentos valleinclanescos, pero hemos de ceñirnos a los dramas rurales que dan título a nuestro trabajo.

Así, pues, aunque Lorca está inmerso en la tradición española al hacer de la tensión de los personajes la base de su obra, también es, y ante todo, enteramente moderno, porque la tensión lorquiana es de una profunda franqueza y está dentro del contexto de lo deseado y posible, son personajes de "carne y hueso" y sus impulsos son del cuerpo y del alma. Junto a ello Lorca barniza todo de una gran sensibilidad.

Pero no sólo en lo citado es novedoso el tratamiento dramático de Lorca sino también en la estructura del orden social en que se enmarcan sus dramas rurales. En los dramas rurales del Siglo de Oro el orden social está identificado con la justicia - con minúscula - (rey, etc.), en cambio en los dramas internos de los personajes lorquianos no es aceptado el dictado del orden social. En el teatro del Siglo de Oro, las motivaciones y los problemas están dibujados con meridiana claridad, en cambio los personajes de García Lorca nunca están seguros su situación total, intentan comprenderse a sí mismos o averiguan sus limitaciones. Pensemos en el caso de la insuficiencia sexual del varón integrada como problema personal, como problema respecto a las necesidades de la mujer y como problema que afecta al código moral y social.

Mientras en los autores del Siglo de Oro y en Benavente los personajes están enclavados en un medio perfectamente controlable, los de Lorca están presididos por una serie de factores que limitan su capacidad de acción y realización de sus anhelos (problemas sociales, biológicos e incluso misteriosos).

Las dicotomías más claras que aparecen en el teatro lorquiano son lo deseado -lo posible, la idea - la realidad, el cuerpo -el alma, el orden individual- el orden social y la tensión que todas estas luchas producen.

(5) BABIN, M.a Teresa: La prosa mágica de Garcia Lorca, Santander, La Isla de los Ratones, 1962 (Col. narración y ensayo). 
La intensidad dramática lorquiana puede medirse dentro del contexto de libre albedrío y determinismo y nuevamente al buscar un nexo de unión entre la tradición dramática española y Lorca nos encontramos una nueva diferencia, en los dramas de Calderón, Tirso o Lope el hombre está enfrentado a un mundo controlable y por su razonamiento puede triunfar sobre el destino. En cambio en Lorca, esta claridad del mundo y este triunfo total sobre el destino, no existirá.

\section{"PLANTEAMIENTO DEL ANALISIS"}

El análisis de la obra de Lorca que vamos a intentar hacer viene determinado por la propia naturaleza del ser humano: ambigüedad, contradicción, suma desconcertante de necesidad y libertad.

Los personajes lorquianos de estas tres obras dramáticas viene a plasmar esta trágica realidad humana: necesidad y libertad. Históricamente estas dos palabras han estado en el fondo de todas las filosofías, así el Idealismo (entendiendo ampliamente esta noción) ha definido al hombre como libertad absoluta, autodominio, independencia..., ante el choque real del hombre con el entorno que lo coarta y lo limita, el Idealismo arrinconó la libertad al mundo interior del pensamiento y del querer, sacrificando -hombre y cosas- con su obrar libre. Igualmente el materialismo (entendiendo, también, ampliamente esta noción) ha definido al hombre como necesidad absoluta, esclavitud; la libertad humana es un mito, un sueño lleno de fantasías e irrealidad.

Lorca sitúa a sus personajes en esa dialéctica, apostando por una sintesis conciliadora. Es decir, para Lorca el hombre es necesidad-libertad, mezcla explosiva de esclavitud y señorio, es un esfuerzo continuo de liberación de sus esclavitudes y violencias.

Los personajes lorquianos surgen en medio de un todo, el todo de la vida, de los instintos, del ser. Como dice $M$. Levinás con "toda la experiencia patética de la humanidad". Es decir, estos personajes se encuentran con un quehacer pero en un medio dado: herencia, salud, familia, momento histórico, espacio geográfico, ideas, creencias, condicionamiento económico, político, social,...

Ante estas "circunstancias" los personajes adoptan dos actitudes: pasiva o activa. Unos tienen la tentación de la pasividad, del conformismo, de la resignación ante unas condiciones físicas y sociales que los esclavizan. Pero otros adoptan actitudes activas, asumiendo los valores de la libertad. de la rebeldía al igual que el "homme revolté" de Camús, o como dijo Sartre "el hombre está condenado a ser libre", consecuentemente los personajes asumen sus roles desde esta contradicción. 


\section{BODAS DE SANGRE}

En esta obra vemos el entramado dramático dentro de los confines del destino y el determinismo. Las navajas parecen tener una influencia malévola que no puede cambiarse. "No sé cómo te atreves a llevar una navaja en tu cuerpo, ni cómo yo dejo a la serpiente dentro del arcón" (6). Todos son víctimas de las armas: "primero, tu padre..., luego, tu hermano" (7). Es evidente que la madre del novio, protagonista de la obra, teme que sea el tercero de su lista de víctimas. Acorde con lo que sucede al final de la obra, sus temores pueden ser considerados como un presagio del destino de su hijo, incluso la imagen de la serpiente ha sido vista por algunos autores (Lichtman) como presagio de muerte. La sensación de destino en estas páginas... (1.1731.174), es obsesiva hasta el punto de que la madre dice: "... me gustaría que fueras una mujer. No te irías al arroyo ahora y bordaríamos las dos cenefas y perritos de lana" (8). La madre no puede luchar contra el destino que parece que se cebará con su hijo.

Pero el determinismo que observamos a través de la gran importancia dada al destino, aparece después como determinismo biológico, social y cultural cuando el novio y la madre hablan de la novia afirmando el primero que es buena y replicando la segunda: "No lo dudo. De todos modos siento no saber cómo fue su madre" (9).

La madre el novio y una vecina hablarán de la madre de la novia afirmando: 1) "No quería al marido". 2) ... "Ella era orgullosa" (10). Esto tendrá gran importancia al final de la obra, cuando la novia engañe al marido.

Pero aún hay más determinismos. Por ejemplo, un determinismo que podríamos denominar de carácter natural aparece en las páginas 1.1971.198 , cuando el padre de la novia trata en una visita del novio y la madre de éste, sobre las tierras de ambas familias, se ve que querría unir las dos propiedades, pero es incapaz de conseguir que sus deseos se cumplan: es una especie de limitación.

Ya en el acto II escena I nos encontramos con dos casos de determinismo biológico y ambiental. Por un lado, la novia dice que su madre procedía de una zona de vegetación exhuberante y la criada le contesta: "Así era de alegre" (11). Por otro lado cuando la novia se queja del gran calor que la consume la criada responde: "El sino". Se establece pues una relación entre los temperamentos de la madre y la hija y el clima en el que se criaron. También nos encontramos en esta misma escena una alusión al destino cuando la criada dice: "Como nos consumimos todas".

(6) Op. cit., pág. 1.172.

(7) Op. cit., pág. 1.173.

(8) Op. cit., pág. 1.174.

(9) Op. cit., pág. 1.176.

(10) Op. cit., pág. 1.181 .

(11) Op. cit., pág. 1.206. 
Cuando Leonardo visita a la novia poco antes de la boda y le habla del desengaño de su propio matrimonio (12) no se considera responsable de ello, ha sido víctima de las circunstancias que han actuado contra él. Así orientado, su matrimonio aparece como determinado por las circunstancias. Por otro lado y comentando la obra en el mismo sentido, observamos que la pasión les tiene dominados. La pasión paraliza su voluntad y puede obligarlos a hacer algo que no desean.

En la página 1.224, la mujer de Leonardo sospecha que algo ocurre: "No sé lo que pasa. Pero pienso y no quiero pensar..." "El mismo sino tuvo $\mathrm{mi}$ madre". Nuevamente aparece el destino como ente irreversible.

En la escena II de este mismo II acto y en la página 1.227, el padre de la novia y la madre del novio ven a Leonardo como un ser humano totalmente determinado por una herencia que él no podrá vencer: "¿Qué sangre va a tener? La de toda su familia. Mana de su bisabuelo, que empezó y sigue en toda la mala ralea, manejadores de cuchillos y gente de la falsa sonrisa".

De esta forma la vida de Leonardo aparece dominada por las circunstancias que traía implícitas su nacimiento. Por otro lado el padre de la novia afirma: "Ese busca la desgracia". Es decir, incluso la desgracia está predestinada porque como afirma después: “... No tiene buena sangre".

Los hombres tienen el sino decidido: "Tienen por fuerza que manejar armas" (13). Y en la misma línea realmente obsesiva de sinos, determinismos y destinos nos encontramos en la página 1.174 , con que su hijo será un buen reproductor, porque procede de buena casta: "Tu abuelo dejó a un hijo en cada esquina". En esta página también el padre de la novia dice querer tener nietos muy pronto: "Lo que quisiera es que ésto fuera cosa de un día". Su deseo no puede satisfacerse: "Se tarda mucho" le replica la madre del novio.

En la página 1.230 , nos encontramos de frente con un ejemplo de determinismo social ha ido mucha gente a festejar la boda porque, como dice la madre al novio: "Tu padre sembró mucho y ahora lo recoges tú". Es una especie de ley de compensación social, comparable al proceso de siembra y cosecha.

Más ejemplos de determinismo natural encontramos en la página 1.234: "Pero, ¿vas a echarme requiebros, niño?” ¡Qué familia la tuya! ¡Machos entre los machos!. Siendo niña vi la boda de tu abuelo ¡Qué figura!. Parecía como si se casara un monte". El novio será viril como instrumento de una buena casta. Igual ejemplo de determinismo natural encontramos en la página 1.239 , cuando la criada dice a la novia: "Una novia de estos montes debe ser fuerte".

(12) Op. cit., pág. 1.214 .

(13) Op. cit., pág. 1.228 . 
En la página 1.240, aparece una concepción de matrimonio como ley oculta, pero segura e inmutable de la naturaleza. Están hablando del día de la boda madre e hijo (novio) y dice la madre que el día de la boda: "Es la roturación de las tierras la plantación de árboles nuevos". Cuando en esta misma página 1240, el novio exclama con respecto al día de la boda: "Mal día para las novias" nos anticipa la catástrofe que se avecina.

En la página 1.241, aparece el novio considerando la obediencia como un deber social: "Yo siempre haré lo que usted mande".

Por lo estudiado y comentado hasta ahora nos podemos hacer una idea bastante clara del enfoque determinista de la obra "Bodas de Sangre", primera de la trilogía que estamos analizando, pero en realidad, este determinismo en el enfoque no es el fin de la obra sino más bien la preparación para las acciones profundamente dramáticas que se'avecinan. No obstante la obra cuando alcance su cumbre emocional también alcanzará el vértice de la concepción determinista en que se mueve la obra, justificándose así todas las afirmaciones y comentarios hechos hasta ahora.

Así, pues, cuando tengan lugar los hechos consumados del desenlace tendremos que recordar y hacernos propia referencia de todo lo anterior. Cuando tiene lugar la huída de Leonardo y la novia, el asunto se desarrolla de tal forma que parece como si Leonardo y la novia hubieran sido empujados a la realización de sus actos mucho antes de realizarlos: "Planta de mala madre, y él, él también, él. Pero ¡ya es la mujer de mi hijo! (14). Es tiempo ahora de recordar las anteriores dudas de la madre del novio sobre la suegra de éste. Igualmente hubo, como recordaremos una referencias anteriores a la mala sangre de Leonardo.

Después de una sugerencia que produce incertidumbre tiene lugar una fuerte afirmación que es el preámbulo del final de la obra, la madre del novio le dice a éste cuando va a salir a la busca de Leonardo: "No. No vayas. Esa gente mata pronto y bien...; pero jsí, corre, y yo detrás!".

La tensión ha estallado, era de esperar pues navajas, mala sangre, etc., estaban latentes hasta que desembocan en el inevitable derramamiento de sangre. El honor debe ahora vencer al sino (inevitable), hay que lavar el honor de la familia.

Es así, como nos adentramos en el acto III, simple confirmación de que el destino ha triunfado. Unos leñadores hablan de la huída de Leonardo y la novia y anticipándose a la acción dicen que morirán Leonardo y el novio (no olvidemos que en toda la obra los personajes están al servicio del destino). Hablando en otros términos existe predisposición en los leñadores para definir determinadas acciones que habrán de ocurrir, surge así de nuevo el determinismo.

(14) Op. cit., pág. 1.244. 
El final que consideran los leñadores está basado totalmente en ese determinismo: "Hay que seguir el camino de la sangre" (15).

Uno de los leñadores afirma que a pesar de sí mismos estaban destinados el uno para el otro. Ambos leñadores confirman el destino especial del novio: encontrará a la pareja furtiva: "Yo la vi salir, como una estrella furiosa. La cara color ceniza. Expresaba el sino de su casta"... "su casta de muertos en mitad de la calle". El modo como morirá el novio estaba ya señalado por el inefable destino, recordemos que en la página 1.229 , la madre del novio dice: "Cuando yo llegué a ver a mi hijo, estaba tumbado en mitad de la calle", y su otro hijo (el novio) morirá por la fuerza de un destino inexorable de la misma manera.

Aparecen ahora la luna y la muerte cargando de catástrofe la escena.

El novio mientras busca a Leonardo nos habla de su brazo, apareciendo éste lleno de su familia muerta y de revancha resumiendo en un brazo que es instrumento más del destino (17). En la página 1.255 , vemos a los leñadores cantando a la muerte, manteniendo un clima de destino.

A continuación aparecen Leonardo y la novia que se saben perseguidos, ella quiere huír de Leonardo pero se siente encadenada a él. No puede por ello ejercer su libre albedrio. Leonardo también aparece como víctima del sino (Es muy significativo ese monólogo que comienza: "¡Qué vidrios..." hasta "que la culpa es de la tierra y de ese olor que te sale de los pechos y de las trenzas" (18). Ha intentado huír de ella pero todas las fuerzas externas estaban contra él. La novia dice saberlo y se sigue presentando como incapaz de resistir a Leonardo.

Es evidente que los personajes son meras víctimas del destino y la naturaleza, pero no debemos olvidar que el honor mancillado del novio debe ser pagado a muy alto precio.

En la página 1.261, nos encontramos con que la muerte de Leonardo y el novio ha tenido lugar, aquí Lorca nos anuncia el luctuoso hecho por medio de las instrucciones escénicas que lógicamente lleva la obra. Se oyen dos largos gritos desgarrados y se corta la música de los violines. Después aparece la muerte pacificada y sometida.

Antes de que al resto de los personajes de la obra les sea confirmada la muerte de Leonardo y el novio, se da por supuesto de que éste ha sido el fin.

A continuacón una vez que el desenlace, preparado por todo el desarrollo de la obra ha tenido lugar, la novia va a hacer las paces con su suegra. Y para ello le explica a la madre de su marido, que le era imposible resistir a Leonardo. Nuevamente un personaje (en este caso la novia) se ve a sí mismo

(15) Op. cit., pág. 1.246.

(16) Op. cit., pág. 1.247.

(17) Op. cit., págs. 1.252-1.253.

(18) Op. cit., págs. 1.257-1.258. 
como producto del destino. Parecía que el honor había sido vencido por la pasión pero en este encuentro entre la suegra y la novia vemos la importancia del código moral en la novia, su rebelión al orden social no es total, el honor restringe finalmente la pasión (19).

La madre del novio termina reconociendo que la novia no tiene la culpa de lo ocurrido, finalmente de la desgracia como obra del destino. La obra finaliza con una nueva referencia a las navajas (20), verdadera obsesión de la madre desde el principio de la obra. La madre del novio queda al final de la obra sola. Celia Lichtman ha hablado de una transformación de esta mujer engendradora de vida a madre dolorosa, según modelo, quizá, de la Virgen de la Soledad.

Las imágenes utilizadas por Lorca a lo largo de la obra son muy numerosas y la enriquecen notablemente. Así vemos como las imágenes utilizadas por el autor nos preparan psicológicamente para el desenlace de la obra.

Uno de los entes que cuenta con más imágenes a lo largo de la obra es la Muerte, no sólo imágenes directas (en forma de mendigo, etc.) sino con múltiples referencias a ella. Por todos los medios la muerte intentará seducir a Leonardo y al novio cosa que, finalmente, consigue. Las imágenes constantes a lo largo de todo el desarrollo de la trama, no sólo servirán para preparar psicológicamente al lector o espectador de la obra, sino también para preparar y anticipar lo que va a acontecer. Las imágenes en muchos casos también completan la estructura de la obra.

\section{CONCLUSION DE “BODAS DE SANGRE”}

Como hemos ido viendo de una manera palpable a lo largo de nuestro estudio de la obra, ésta está concebida dentro de notable determinismo, tomando gran importancia el sino como motor esencial, también, de la obra. El determinismo del que tanto hemos hablado se mueve en dos estadios: biológico y social, encontrándose al servicio del sino, verdadera clave de la obra desde los primeros momentos y que se hará más ostensible conforme nos acerquemos al final. La obra es un típico "triángulo amoroso", y asimismo, los tres componentes de este triángulo se encuentran totalmente dominados como meras herramientas del determinismo y el sino. La acción secundaria en esta obra reviste especial importancia porque es un apoyo eficacísimo a la trama principal.

Como hemos indicado las imágenes realizan tres misiones esencialmente:

1.-Completan la trama.

(19) Op. cit., pág. 1.270.

(20) Op. cit., pág. 1.272. 
2.-Crean incertidumbre preparando psicológicamente al espectador de la obra.

3.-Evocan sucesos de la acción principal que no se han visto en el escenario, que tuvieron lugar fuera de él, y que a través de las imágenes se dan por vistos y sobreentendidos.

Resumiendo y concluyendo podemos indicar que "Bodas de Sangre" es un drama dedicado a un amor frustrado con las siguientes notas más significativas:

a) Código social restrictivo.

b) Miedo a la muerte.

c) Sangre como verdadera obsesión de los protagonistas.

d) Insuficiencia sexual del varón.

e) Destino como alma de la trama.

f) Sino que llega a sus designios por un determinismo biológico y social.

g) Los personajes son instrumentos del destino.

h) Casi nulas posibilidades para los protagonistas de obrar libremente.

i) Gran importancia de las imágenes.

YERMA (21).

El drama de la obra es la necesidad imperiosa por parte de la protagonista de averiguar si sus inseguridades intuitivas y psíquicas acerca de su capacidad como mujer son ciertas o no.

Esta es la verdadera clave de la obra. Es una constante lucha entre lo que quiere Yerma y lo que se presenta como su destino, o lo que es lo mismo, entre su propia voluntad y lo que está predestinado.

Esa gran necesidad de Yerma, esa ambición por tener hijos se presenta de una forma clarísima desde los primeros momentos del acto 1.0 . Le recuerda a su esposo que llevan dos años casados y aún no han tenido hijos. El conflicto se agudiza cuando aparece María que está encinta después de tan sólo cinco meses de casada. Yerma verá el estado de María como algo que la excita y le atrae ostensiblemente. De ahí sus continuas preguntas a ésta. Una de las preguntas más significativas de las que Yerma hace a María es: "Dime, ¿tú estabas descuidada?" (22) a lo que María responde que sí. Como veremos más adelante Yerma ha tratado de concebir sin ningún resultado positivo. Con ésto aparece un determinismo biológico claro: María, sin querer,

(21) Federico dice de esta obra: Yerma será la tragedia de la mujer estéril. El tema, como usted sabe, es clásico. Pero yo quiero que tenga un desarrollo y una intención nuevos. Una tragedia con cuatro personajes principales y coros, como han de ser las tragedias. Hay que volver a la tragedia. Nos obliga a ello la tradición de nuestro teatro dramático". Op. cit., pág. 1.759.

(22) Op. cit., pág. 1.279. 
ha quedado encinta, Yerma, deseándolo vivamente, no lo ha conseguido. Así, pues, el determinismo biológico actúa desde un primer momento como propulsor de la obra, como obsesión de Yerma.

Entre todas las mujeres que se casan por su época Yerma es la única aún no embarazada, lo que le ha acarreado una gran frustración. Reconoce lo grave de su problema. Hará esfuerzos para ayudar a su fertilización entrando en contacto con la madre tierra. Ella sospecha de su insuficiencia sexual y este pensamiento la atormenta implacablemente. El drama de Yerma es que no acepta la esterilidad y considera como función primordial de la mujer tèner hijos. Es muy significativo el texto siguiente de la obra: "Tener un hijo no es tener un ramo de rosas. Hemos de sufrir para verlos crecer. Yo pienso que se nos va la mitad de nuestra sangre. Pero ésto es bueno, sano, hermoso. Cada mujer tiene sangre para cuatro o cinco hijos, y cuando no los tienen se les vuelve veneno, como me va a pasar a mi" (23). En el texto anterior podemos encontrar algunas jugosas conclusiones:

1.-Expresa el esquema social en que debe juzgar sus logros como mujer, es decir, ser madre es la señal de estar realizada.

2. - La madre aún en el placer soporta el dolor.

3.-Sensación de frustración.

4.-Fuerte premonición de no poder librarse de ella ("..., como me va a pasar a mi").

Pero todo lo dicho no indica que ella conozca su destino, porque Yerma no lo considerará una realidad hasta que la atenaza.

Ya adentrados en el cuadro segundo del acto I vemos que Yerma se encuentra con una vieja, lo que le produce una sensación de bienestar, porque ve que ella puede ayudarle a quedar encinta, pero la vieja se ve incapaz de ello, ya que la concepción se ve regida por unas leyes biológicas fuera de la voluntad humana. La vieja intentando ayudar a Yerma a solucionar su problema le pregunta si ama a su marido (Juan), ella dice que casó con él porque su padre lo eligió como su esposo, pero que ella quiere realmente a Víctor. Yerma dice haber aceptado (pese a todo) a Juan con alegría con lo que nos podemos percatar de la gran importancia de la costumbre y obediencia. La vieja dice que quizá no haya quedado preñada por esta razón: "Los hombres tienen que gustar..." (24). Yerma no queda convencida por la vieja y ve su problema sólo solucionable por Dios. La vieja dice no creer en él, pero añade (y ésto es muy importante): "Aunque debía haber Dios, aunque fuera pequeñito, para que mandara rayo contra los hombres de simiente podrida que encharcan la alegría de los campos" (25).

(23) Op. cit., pág. 1.283 .

(24) Op. cit., pág. 1.290.

(25) Op. cit., pág. 1.291. 
Surge asi la sugerencia de que Juan pueda ser impotente. Esta ha surgido ya anteriormente en boca de Víctor; con referencia al coito dice: "... y en cuanto a lo otro, ique ahonde! (26). Así, pues, no sabemos cual de los dos (Yerma o Juan) será estéril, con este oscurecimiento deliberado del asunto por parte de Lorca, el autor aumenta las posiblidades dramáticas de la obra. Yerma al no saber si su esposo es impotente o no, se ha acusado a sí misma, aumentando la tensión en la obra e incluyendo al lector o espectador en una búsqueda de autocomprensión y definición.

La ya mencionada vieja, al partir recalca que es imposible cambiar la situación de Yerma: "Espera en firme. Eres muy joven todavía" (27). Yerma se para a hablar con la denominada muchacha $2 .^{a}$ que está casada, pero que no desea tener hijos. Yerma le pregunta que entonces por qué se casó, y la muchacha replica atacando a la tradición y al convencionalismo represivo que no responde a sus necesidades y deseos, por otro lado apunta hacia una mayor libertad sexual: "¿Qué necesidad tiene mi marido de ser mi marido? Porque lo mismo hacíamos de novios que ahora. Tonterías de los viejos" (28).

La tradición aparece en opinión de la muchacha $2 .{ }^{a}$ como limitadora de la libertad, ella se opone a ésto: aunque el mundo esté esclavizado haciendo lo que se "debe hacer" y lo que no se quiere, ella insistirá en elegir siempre que pueda.

Yerma y Víctor, como he indicado anteriormente están enamorados y sienten atracción física mutua. García Lorca los reune por medio de una canción popular puesta en boca de Víctor (29). En la página 1.297, observamos una lucha entre lo que la biología les dicta y las prohibiciones del orden social. Es una suprema prueba de voluntad. El profundo silencio que se produce entre Yerma y Victor, es una auténtica lucha psicológica significativa incluso sexualmente (Estamos hablando de la página 1.298).

La lucha ya referida entre lo natural y el código moral, termina con el triunfo del segundo. Aparece entonces en escena, Juan, marido de Yerma. Vemos como éste no está preocupado por lo mismo que Yerma, a él le interesa el progreso material y la riqueza, no compartirá la cama con Yerma, tiene que atender a sus deberes: “... y tengo que defenderla (agua) de los ladrones. Te acuestas y te duermes" (30) Las salidas nocturnas de Juan al campor por la noche pueden ser interpretadas como un intento de evadir sus deberes maritales hacia Yerma. $\mathrm{Ha}$ habido algunas indicaciones anteriores

(26) Op. cit., pág. 1.285 .

(27) Op. cit., pág. 1.291 .

(28) Op. cit., pág. 1.293 .

(29) Op. cit., pág. 1.295.

(30) Op. cit., pág. 1.300 . 
de su insuficiencia sexual que apoyan ésto. Juan se ocupa del agua para fecundar la tierra, $y$, en cambio, descuida esa misma necesidad de su esposa. Podría interpretarse así su acción de fertilizar la tierra como un sustituto de su incapacidad para fecundar a Yerma.

En el acto segundo nos encontramos en un centro de murmuraciones: el lavadero, con ello García Lorca no quiere más que darnos la imagen de la reacción del mundo exterior ante la situación personal de Yerma. El honor aparece como lo más importante de la escena. Surgen murmuraciones y preguntas, seguidamente, acerca del extrafio comportamiento de Yerma. Según lả conversación de las cinco lavanderas podemos concluir que, según ellas, tiene hijos quien quiere tenerlos. Sabemos que este no es el caso de Yerma que los desea vivamente, pero ésta es la visión pública del personaje. Pero la discusión se lleva más lejos y se formulan calumnias sobre el carácter de Yerma y se le acusa de ir en busca de otro que no es su marido. El pueblo ha descu bierto el triángulo amoroso, que, por cierto, no está totalmente cerrado para el espectador ya que Víctor hasta ahora se ha mantenido en silencio al respecto. Aunque la gente está equivocada y quedan muchos "huecos" por llenar el que se haya fabricado la situación descrita basta para empañar el honor del marido de Yerma, y éste lo sabe. Ya se adivina el final de la acción principal, por medio de las acciones secundarias, pero todo queda en mera pista. En las páginas 1.303-1.304, se está sugiriendo la posibilidad de que el triángulo se esté convirtiendo en algo violento y apasionado.

Juan, mientras, ante estas supuestas relaciones amorosas de su mujer: "está parado como un lagarto al sol" (31). La insinuación de comparar a Juan con un lagarto al sol (falta de agua, etc.) puede ser un apoyo más a la idea de que el marido de Yerma es impotente. Pero todo son insinuaciones. Lorca al contrario que Lope o Tirso, no aclara totalmente, trabaja en la penumbra, crea una tensión especial, caracteristica fundamental de la tragedia moderna.

Ante el problema que acaba de plantearse entre Juan y Yerma hay dos explicaciones:

1. - La lavandera 1. a piensa que todo iría bien si tuvieran hijos.

2. - La lavandera 2. a opina que "Todo ésto son cuestiones de gente que no tiene conformidad con su sino" (32).

En este segundo caso todo parece indicar que si los dos esposos pudieran ordenar sus vidas de acuerdo con su sino habría paz para ellos. Pero Yerma se negará a aceptar su sino y por ello no encontrará la paz.

A continuación las lavanderas se dedican a inculpar a uno y a otro de la situación a que han llegado, dividiéndose en sus opiniones, dejan de discutir acerca del tema porque aparecen las cunadas de Yerma en escena.

(31) Op. cit., pág. 1.304.

(32) Op. cit., pág. 1.304 . 
En la escena segunda del acto II, vuelve a aparecer, el antes esbozado tema del honor. Juan dice a sus hermanas que no quiere que Yerma salga a la calle sin necesidad porque: "... Mi vida está en el campo, pero mi honra está aquí. Y mi honra es también la vuestra". Pero estas prohibiciones sólo podrían tener realización si él permaneciese en casa y le proporcionara a Yerma lo que tanto necesita. Yerma dice a Juan que se quedará en la casa si en ella hubiera vida. Juan le dice que no le falta nada (a Yerma) que cuando sale al campo a dormir solo, quiere estar seguro de que ella duerme también. Yerma le replica: "Pero yo no duermo, yo no puedo dormir" (33) ..."pero yo no soy tú. Los hombres tienen otra vida..." El papel de la mujer en la sociedad ( $y$ en él quiere encajar Yerma) es el de tener y criar hijos. El propio concepto que tiene Yerma de sí misma aquí está planteado fuertemente en términos de realización biológica.

Yerma transmite parte de su tensión a su marido que le sugiere (como las lavanderas) resignación. El problema está en que Yerma no acepta su sino. Se casó para tener hijos y no se resigna a ello.

En la página 1.314, Yerma expresa su esterilidad en sentido figurado. A continuación Juan acusa a Yerma: "Lo que pasa es que no eres una mujer verdadera y buscas la ruina de un hombre sin voluntad". Yerma le dirá: "Yo no sé quién soy. Déjame andar y desahogarme" (34). Está tensión y angustia durará mientras trata de descubrir quién es realmente. Esta ambigüedad es algo característico de Lorca que no aparece en los dramas del Siglo de Oro; en éstos no existe la tensión del autodescubrimiento. En Yerma, ni los protagonistas ni ella misma saben quién es realmente y lo mismo le pasa a todos los que están fuera de la obra (espectadores o lectores).

En la página 1.316, Yerma comienza a cantar (como soñando, según indica el propio Lorca). En la canción de Yerma expresa su gran necesidad de tener un hijo y sugiere varias facetas de todo el ciclo vital. Nuestra protagonista ve que debe tener hijos como parte de este ciclo eterno. Es decir, concibe sus necesidades en el marco de un ciclo biológico muy amplio. Aparece nuevamente el determinismo biológico. En una conversación que tiene Yerma con María (35), Yerma en forma positiva se reafirma en que necesita la belleza de la maternidad un florecimiento de compasión y ternura en su interior. María, para consolarla, le dice que hay otras cosas que pueden darle la felicidad, pero Yerma no se convence y al afirmar: "Yo no debo tener manos de madre" parece que si se viera a sí misma como algo malo, condenado por Dios. Su propósito de tener hijos es bueno, como no lo ha realizado es mala y deben negársele incluso los pequeños placeres. Esta es la autorreflexión que hace Yerma, amargada por su obsesión y frustración.

(33) Op. cit., pág. 1.313.

(34) Op. cit., pág. 1.315.

(35) Op. cit., pág. 1.317. 
Hay que señalar aquí que Yerma no es presentada como envidiosa, para mantener la intensidad de la acción; Lorca no necesita recurrir a que Yerma sienta envidia por María (que ha realizado el gran sueño de nuestra protagonista) para que el drama tenga garra propia.

A lo largo de la obra vamos observando en numerosos detalles lo profundo y grande de la frustración que aqueja a Yerma. Es también, reseñable que a medida que la trama avanza se van haciendo mayores, lo que nos hace presagiar un final explosivo.

Para Yerma nuestras vidas tienen un fin metafísico del que no podemos salir (es decir, un sino).

Otro punto muy importante es que Yerma considera a su honor por encima de todo: "Lo primero de mi casta es la honradez" (36).

Pero, no sólo la mujer debe entrar por ciertos esquemas, ya mencionados anteriormente; también el hombre debe respetar los suyos.

En la página 1.323, observamos cómo Víctor no participa de la fuerte pasión de Yerma, al fin y a la postre en él no existe la frustración ni la tensión interna de Yerma.

Víctor desaparece de escena sin completar el triángulo amoroso, las dudas de lavanderas, etc., no han resultado falsas. Así, pues, García Lorca, no va a utilizar el "triángulo" como desencadenante del climax.

En el acto III, Yerma acude a una conjuradora que le anuncia que va a tener un hijo, cuando Yerma replica: "Lo tendré porque lo tengo que tener (37)", sigue dando importancia a su fuerte voluntad y deseo que pueden producirle felices resultados. Yerma quiere tener un hijo pese a los consejos de la vieja $1 .^{\mathrm{a}}$, no le importa morir en el intento, para ser realmente libre necesita realizarse como madre a toda costa.

Es imprescindible señalar que Yerma considera a su marido como frígido sexualmente ("Cuando me cubre cumple con su deber...") (38) con lo que no debemos perder de vista el argumento de que Juan sea estéril.

Para Yerma (en contra de las leyes biológicas) tener un hijo, por lo que ello no se cumple. No es el amor lo que se necesita para ser concebida, sino la necesidad y el deseo de reproducción.

$\mathrm{Al}$ ser fiel a su marido por leyes sociales, pese a sus dudas sobre la capacidad de Juan, ésta es la única salvación para Yerma. Yerma da gran importancia (como tantos otros personajes lorquianos) al poder de la sociedad.

Juan acusa en la página 1.333, a Yerma de infidelidad defendiéndose impetuosamente de Yerma. Juan dice que él sólo recoge los rumores de la calle que, naturalmente, le afectan. Cuando el marido de Yerma le pregunta a

(36) Op. cit., pág. 1.319

(37) Op. cit., pág. 1.328

(38) Op. cit., pág. 1.329 . 
ésta qué busca en la calle, ella le replica que a él, pero Juan aparta a Yerma de sí. Entonces nuestra protagonista maldice su linaje que parece que lleva en sí la esterilidad. Juan intenta callar a Yerma que no lo hace, creándose con la contestación que da, un paralelismo entre el querer llevarla a la fuerza y no poder hacerlo, y el quererla "con la cabeza" y no en términos sensuales.

En la página 1.335, Yerma parece que se resigna a su sino: “¡Ya está! ¡Que mi boca queda muda!". Pero esta resignación no es real, ni le acarreará la paz interior.

En el cuadro segundo del acto III, ambientado en una romería-peregrinación de las mujeres $\sin$ hijos para pedir ser concebidas.

La escena de la romería está impregnada de un gran significado sexual y fertilizador. Yerma se une al ceremonial como último recursos para ser madre. Una vez agotados los cauces humanos, Yerma recurre a lo mistérico y ritual.

Tras estas ceremonias de la romería la vieja $1 .^{\mathrm{a}}$ le dice a Yerma que es Juan el culpable de que no tengan hijos, es él, el que es estéril, además ello le viene de casta. La herencia es utilizada como argumento de gran peso por la vieja, Yerma procede de línea fértil mientras Juan procede de una línea estéril. Nuevamente encontramos elementos de determinismo natural. Según todo ésto, a Yerma sólo le queda una alternativa para quedar encinta: buscar un hombre fértil, las mujeres que han ido a la romería lo han hecho para tener relaciones con otras parejas a fin de ser concebidas. La vieja le ofrece a Yerma a su hijo como pareja ideal. Actúa aquí la vieja como auténtica alcahueta. Pero esta solución que le ofrece es rechazada por Yerma indignada; su honor y su honra son demasiado importantes para ella. Por otro lado cuando afirma "Yo no puedo ir a buscar" es consciente del valor y la misión social de la mujer: debe a traer al varón pero nunca buscarlo.

Así, pues, la libre elección que Lorca da a Yerma no es absoluta, para conseguir un propósito tendría que humillarse, las tenazas del orden social y los tabúes no la dejan obrar libremente. En esta escena se han visto similitudes con el acto IV de la Celestina (vieja $1 .^{\mathrm{a}}$ - Celestina - Yerma - Melibea).

Cuando la vieja acusa a Yerma de "marchita" (39) da con la palabra clave de la obra. Se ha confirmado que Yerma ha rumiado durante mucho tiempo; el drama de Yerma queda ahora perfectamente perfilado como tortura interna.

Yerma no está sola en la romería. Juan también está y ha oído lo que la vieja le ha dicho a su mujer. Juan le recomienda que no se atormente, porque no puede cambiar su sino. Parece aclararse que ambos (Juan y Yerma) son estériles pero no por ello disminuye la intensidad del drama. Juan no ha querido nunca tener hijos. Le importaba muy poco tener o no hijos. Ante esta

(39) Op. cit., pág. 1.345 . 
afirmación Yerma se hinca de rodillas totalmente desesperada. Juan continúa intentando convencer a Yerma que ninguno de los dos es culpable, no tienen capacidad para decidir su potencia para tener hijos. Pero esta opinión no es aceptada por Yerma. Entre las páginas 1.348-1.349, se entabla un intensísimo diálogo entre los dos esposos en el que se clarifican más aún las posiciones: resignación de Juan, inconformismo de Yerma. Juan dice amar a Yerma, pero el amor es interpretado por Juan en sí mismo y ésto no es suficiente para Yerma. Esta, en su deseperación, estrangula a Juan diciendo: "Marchita, marchita pero segura. Ahora sí que lo sé de cierto y sola. Voy a descansar sin despertarme sobresaltada para ver si la sangre me anuncia otra sangre nueva. Con el cuerpo seco para siempre" (40).

A la gente de la romería que se acerca le increpa: “ ¡No os acerquéis, porque he matado a mi hijo, yo misma he matado a mi hijo!".

Al concluir la obra aún pueden oírse los ritos de la romería (el ritual de la fertilidad continúa, pues). Vemos una dicotomía divergente y extrema entre los dos extremos del ciclo vital: por un lado el rito de la fertilidad, por otro la aceptación irrevocable de su sino por parte de Yerma. Con la aceptación de su destino irrevocable Yerma termina con su agitación, vivirá marchita pero segura. Al no tener hijos. Podrá decir que en la flor de la vida murió su marido y por ello no tuvo hijos, de ahi que al final de la obra exclama que ha matado a su hijo al matar a su marido.

La obra termina no con el triunfo del destino, sino con la aceptación de éste por parte de Yerma.

Como ocurre en Bodas de Sangre, en "Yerma", Lorca echa mano de las imágenes y de una manera especial en la escena de la romería, así el agua del río que fertiliza el terreno yermo la rosa (órganos reproductores femeninos), máscaras (nos indican que se desarrolla una danza de fertilidad), aparece un cuerno de oro en las instrucciones escénicas dadas por Lorca que nos pueden indicar la próxima infidelidad de muchas esposas. Igualmente las imágenes sensuales son muy numerosas en la escena de la danza del macho con la hembra.

La romería trata de celebrar y exteriorizar (además de propiciar por medio de la ceremonia) una etapa natural del ciclo vital. Las leyes de fertilidad pretenden operar de un modo positivo en Yerma, pero esa se niega, por los valores propios de la sociedad de la que no se ha desligado. En vista de un dilema, Yerma optará por el asesinato. Por otro lado, hay que indicar que Lorca no nos muestra la moralidad o inmoralidad de la acción, simplemente la relaciona con el ciclo vital.

(40) Op. cit., pág. 1.350. 


\section{CONCLUSIONES}

Las principales consecuencias que he podido sacar de la lectura de Yerma son las siguientes:

a) El destino se cierra sobre Yerma.

b) Determinismo natural (opinión de Yerma acerca de sí misma y de la herencia).

c) Yerma considera su papel en meros términos de reproducción.

d) Determinismo social en dos vertientes: imagen social de la madre y honor.

e) Tensión constante basada en dudas, contradicciones biológicas, sociales, etc. ría).

f) Imágenes utilizadas para propiciar la felicidad (escena de la rome-

g) Objetivación de la obsesión básica de Yerma en el sentido de una necesidad de la tierra, es decir, la perpetuación del ciclo vital.

h) Triunfo final del código moral frente a los incentivos que supone la lección de fertilidad a los ojos de la protagonista.

Podemos resumir la obra así: Yerma es un drama en que se abordan los temas de una maternidad frustrada y la pareja sexual masculina inadecuada. Como en "Bodas de Sangre" podemos advertir la presencia del destino desde el principio; la protagonista luchará a lo largo de toda la trama para que su sino no se cumpla y su vida pueda así colmarse teniendo hijos. Pero el destino triunfará (como ocurre igualmente en Bodas de Sangre) por un determinismo social que ayudará poderosamente al triunfo final de aquel. Por último las imágenes utilizadas exteriorizarán y objetivarán a los ojos del lector 0 espectador los aspectos sensuales de la obsesión de Yerma.

\section{LA CASA DE BERNALDA ALBA}

Esta obra es un continua lucha entre el libre albedrío y sus fuerzas contrarias. Como la obra está enfocada directamente en esta lucha máxima entre determinismo y libertad de acción, hacia ello orientaremos nuestro comentario. Y para ello comenzaremos nuestro estudio por el acto II. Pero antes situemos la obra. Bernalda Alba es una viuda (la obra comienza precisamente con el entierro de su marido) con varias hijas, todas ellas solteras. Toda la obra reflejará la lucha de todos los personajes dentro de las cuatro paredes de la Casa de Bernalda en la que prácticamente se encuentran enclaustradas. La obra es un verdadero panel en el que se reflejan todos los deseos reprimidos y frustraciones de los personajes.

Como decíamos, vamos a iniciar nuestro comentario a partir del acto II. 
En él, Angustias, la hija mayor de Bernalda tiene un pretendiente. El comentario que hace Angustias en este II acto es harto significativo: "Afortunadamente, pronto voy a salir de este infierno" (41). Esta imagen es lo suficientemente dura y profunda como para poder sacar prácticamente la tesis, o una de las tesis de la obra: vivir en casa de Bernalda Alba se ha convertido desde un principio en algo insoportable para las ocupantes de ella; pero ésto tiene unos motivos y a ellos iremos a lo largo del comentario que nos proponemos realizar.

Poncia, la criada de la casa, viene a poner especial énfasis en el modo de vida de la casa de Bernalda cuando afirma: "Ya me ha tocado en suerte este convento" (42). Aquí ya podemos esbozar que tiene que haber una "madre superiora" para que la imagen sea perfecta, esta "madre" que dicta las reglas del "convento" y tienen completa autoridad sobre las monjas, es Bernalda, la dueña de la casa, como podemos fácilmente deducir de una lectura rápida de la obra. Esta "madre superiora" regulará todos los aspectos de la vida, por tanto el libre albedrío no podrá ser ejercido por las hijas de Bernalda, en este caso "monjas" de ese "convento" al que se refiere Poncia.

En el Acto III nos encontramos una escena tan significativa o más que las dos apuntadas, Poncia dice a Bernalda: "Tus hijas estạ́n y viven como metidas en alacenas" (43). Asi pues, desde un primer momento queremos en nuestro trabajo dejar bien claro el determinismo impuesto por Bernalda a sus hijas, y la obra nos lo va confirmando según profundizamos en su lectura. $Y$ en este mismo acto, ya muy avanzada la acción la misma Poncia dice que querría: “...dejar esta casa de guerra" (44). Esta afirmación de la criada merece una atención especial.

A través de estas palabras ya no nos cabrá la duda de que La Casa de Bernalda Alba es una lucha constante de lo que en ella moran por hacer prevalecer su libertad frente a las fuerzas adversas (Bernalda Alba) que son muy poderosas.

No podemos seguir adelante en nuestro comentario sin decir unas breves características de nuestra protagonista antes. En Bernalda la voluntad es dominante hasta el punto que lo que la rodean no pueden ser libres, pues están sometidos a su dominio sin límites. Así Bernalda Alba es una especie de tirana que no tiene en cuenta a los demás, sino a sí misma, Y en un momento de la obra, Poncia, la vieja criada, la tacha de " $¡$ Mandona! „Dominanta! ... Tirana de todos lo que la rodean".

(41) Op. cit., pág. 1.483

(42) Op. cit., pág. 1.484.

(43) Op. cit., pág. 1.518 .

(44) Op. cit., pág. 1.521 . 
Los personajes que viven con Bernalda son conscientes de que están dominados por ella, y así lo reconoce La Poncia, cuando dice:

"Pero yo soy buena perra; ladro cuando me lo dicen y muerdo los talones de los que piden limosna cuando ella me azuza ..." (45).

Y desde un primer momento vemos con Bernalda Alba tiene un absoluto domino sobre las gentes que habitan su casa. Esta dará instrucciones a sus hijas de lo que deberán hacer en los "ocho años que dura el luto" (46). Pero lo más grave, no es que lo imponga como norma, sino que además lo ampara y refuerza en la tradición y en el determinismo cultural: "Así pasó en casa de mi padre y en casa de mi abuelo" (47).

Sabemos que los personajes odian estar dentro de aquellas paredes. Magdalena dice: "Todo menos estar sentada días y días dentro de esta sala oscura" (48). Bernalda le dirá a Magdalena que el papel de la mujer es estar en casa (nuevo caso de amparo del domino de Bernalda en determinismo cultural) y además continúa diciendo: "Aquí se hace lo que yo mando. (...) Hilo y aguja para las hembras. Látigo y mula para el varón. Eso tiene la gente que nace con posibles" (49). Esta última afirmación de Bernalda hace una clarísima referencia al determinismo social, del que Bernalda tiene verdadera conciencia de clase.

El determinismo natural o biológico, que aparece ampliamente en "Yerma" y "Bodas de Sangre", resurge en "La casa de Bernalda Alba", y prácticamente desde un principio, pues Bernalda al hablar de su madre dice: "Tiene a quien parecerse. Mi abuelo fue igual" (50). Cuando se habla de una tal "Paca La Roseta", se dice que es la única mujer "mala" que hay en el pueblo, y Poncia lo explica: "Porque no es de aquí. Es de muy lejos. Y los hombres que fueron con ella son también hijos de forasteros. Los hombres de aquí no son capaces de eso" (51). Aquí se confunden tanto el determinismo natural como el cultural, apoyándose en un posible determinismo geográfico.

A partir de ahora vamos a intentar analizar los personajes opuestos a Bernalda, es decir, sus hijas, una vez que hemos introducido y justificado este trabajo como determinismo lorquiano.

Aunque todas las hijas de Bernalda están "en edad de merecer" como dice Poncia, pueden vivir sin hombres porque Bernalda Alba lo dice: ¡No ha

(45) Op. cit., pág. 1.442

(46) Op. cit., pág. 1.451 .

(47) Op. cit., pág. 1.451 .

(48) Op. cit. pág. 1.452 .

(49) Op. cit., pág. 1.452 .

(50) Op. cit., pág. 1.452 .

(51) Op. cit., pág. 1.456 . 
tenido novio ninguna ni les hace falta! Pueden pasarse muy bien" (52).

Martirio, una de las hijas de Bernalda, ve las circunstancias de su vida desde el punto de vista de que no puede cambiarlas, es decir, su vida está dominada por el sino. El concepto, por otra parte, que tiene esta hija de Bernalda de los hombres es totalmente negativo y determinista:

"A ellos les importa la tierra, las yuntas, y una perra sumisa que les de de comer" (53).

Ve a la naturaleza del hombre como algo incapaz de cambiar. Cuando aparezca Pepe el Romano, única figura masculina reseñable en la obra, veremos que responde a la concepción de Martirio: hombre con corrompida naturaleza fija y predeterminada.

Adela es la más contestataria de todas las hijas, es la más joven y la que más fuertemente se opone a su sino. Adela aparece siempre buscando alternativas y realizando elecciones. Amelia cuando analiza la actuación de Adela exclama: " $i \mathrm{Si}$ te ve nuestra madre te arrastra por el pelo"! (54). Vemos, pues, que Adela ejerce su libre albedrío aunque a escondidas. Los ideales de Adela son considerados por sus hermanas como ilusiones de la edad y que no podrá alcanzarlos, pero Adela llevará su lucha por su libertad hasta la muerte.

Adela, la única hija de Bernalda que luchará por engañar a su destino, está enamorada de Pepe el Romano, como veremos más adelante. Conforme las hijas van hablando del "Romano" el concepto determinista de hombre se irá trazando con rasgos cada vez más fuertes.

Hemos dicho que Adela es la más luchadora de todas las hermanas, pero no es la única que se opone a los designios de Bernalda, Angustias fortalecida por su futuro matrimonio realizará acciones que van en contra de los deseos de su madre, pero Bernalda terminará ejerciendo su voluntad (escena en que Angustias se aplica los polvos y Bernalda se los quita violentamente). Ante la pequefia revolución hecha por Angustias, Bernalda aprovechará para decir que: " $¡$ Hasta que salga de esta casa con los pies adelante mandará en lo mío y en lo vuestro!" (55). Cuando concluye el primer acto, María Josefa (madre de Bernalda) dirá lo que es y será el destino de las hijas de Bernalda: "Ninguna de vosotras se va a casar. ¡Ninguna!" (56).

Es curioso resaltar que el casamiento es la única salida que ven las hijas de Bernalda para librarse de su destino, se consumen por casarse. Su destino se hace más amargo e irreversible al no poder hacerlo. María Josefa, el único

(52) Op. cit., pág. 1.457 .

(53) Op. cit., pág. 1.460 .

(54) Op. cit., pág. 1.465 .

(55) Op. cit., pág. 1.470 .

(56) Op. cit., pág. 1.470 . 
personaje que se enfrenta con Bernalda Alba y le combate, aparece como loca y permanece encerrada por obra de Bernalda. Así al final del acto y, María Josefa habla más de la cuenta y Bernalda manda que la encierren.

Hemos dicho que el concepto de "hombre" que aparece en la obra es totalmente negativo, así la Poncia abunda en esta idea con su experiencia: "A vosotras que sois solteras, os conviene saber que de todos modos el hombre, a los quince días de boda, deja la cama por la mesa y luego la mesa por la tabernilla, y la que no se conforma se pudre llorando en un rincón" (57).

Casi al principio del Acto II nos encontramos con la afirmación de que Adela está obrando con independencia. Por ello será vigilada y censurada en sus acciones por sus hermanas. Adela se sentirá perseguida por sus hermanas. Es interesante reseñar que en esta misma situación aparece el cuerpo (en sentido físico) como una fuerza muy poderosa. El cuerpo tiene un lugar preminente en la escala de valores de Adela. Definirá su libertad en cómo usar su cuerpo libremente: "Mi cuerpo será de quien yo quiera" (58). Adela obrará positivamente para realizar sus deseos: así podemos observarlo en su acción de casi desnudarse cuando Pepe el Romano iba a visitar a su hermana, según nos indica Poncia en la página 1.481 .

Con ésto podemos intuir fácilmente que Pepe el Romano entra en los planes de liberación de Adela, Pepe corteja a Angustias, su hermana; esta relación debía ser respetada por ella pero no lo hace, las exigencias de la sociedad no son consideradas por nuestro personaje como fuerza coaccionadora suficiente de su libertad personal.

Poncia le dice a Adela que olvide el amor de Pepe, que espera a que Angustias se muera: "... pero no vayas contra le ley de Dios" (59). Pero Adela no respetará estas tradiciones que pretenden actuar como determinismo social. Poncia como ve imposible convencer a Adela presagia la tragedia que se avecina y no quiere que tenga lugar, no por lo que las quiere, sino porque quiere: "vivir en una casa decente" (60) (sabe el escándalo que puede producirse). Pero Adela le replica: "Es inútil tu consejo. Ya es tarde" (61). El destino está ya, pues, en marcha. Pero es significativo que aunque Adela lucha por hacer algo por encima de todos, no lo hace pensando en que realiza una elección libremente sino que se ve a sí misma como un instrumento de las fuerzas internas que la empujan ("... por encima de mi madre saltaría para apagarme este fuego que tengo levantado por piernas y boca" (62). Adela recalca la importancia del sino: "Nadie podrá evitar que suceda lo que tiene que suceder" (63).

(57) Op. cit., pág. 1.476.

(58) Op. cit., pág. 1.479.

(59) Op. cit., pág. 1.481 .

(60) Op. cit., pág. 1.482 .

(61) Op. cit., pág. 1.482

(62) Op. cit., pág. 1.482 .

(63) Op. cit., pág. 1.482 . 
El determinismo cultural tiene una gran importancia en "La Casa de Bernalda Alba", hasta el punto de que ha dominado fácilmente a sus hijas por que éstas no se han rebelado contra la tradición. Magdalena afirma en un pasaje de la obra, para corroborar ésto, que: "Cada clase tiene que hacer lo suyo" (64). Más adelante vemos cómo las protagonistas de nuestra obra consideran el nacer mujer como la peor de las penas, las mujeres tendrán una moral estricta, al contario que los hombres con una moral más abierta.

Cuando Martirio afirma: "Me sienta mal el calor" (65), podemos ver una referencia a la fiebre sexual que la oprime y no puede satisfacer. Es hora ya de 'decir, aunque se ha podido suponer, que la represión sexual es una de las características más acusadas de todas las hijas de Bernalda Alba y ello se deriva claramente de las precarias circunstancias de vida, totalmente falta de libertad, que les ha proporcionado su madre.

Podemos percatarnos aún más de la estrechez de la moral imperante en la casa en el suceso de la desaparición de la foto de Pepe el Romano que tenía Angustias, ésto es visto como algo escandaloso por Bernalda: "Me hacéis al final de mi vida beber el veneno más amargo que una madre puede resistir" (66). Cuando nos enteramos de que ha sido Martirio la que robó la foto, vamos a ver a Bernalda Alba maldiciendo a su hija, con lo que podemos concluir la gran importancia dada por Bernalda al incidente.

Como resultado del incidente antes descrito tiene lugar una disputa entre las hermanas. Bernalda dice: "Yo veía la tormenta venir, pero no creía que estallara tan pronto" (67). No podrá ocurrir de otra manera, es el destino.

Cuando Poncia echa en cara a Bernalda Alba que no ha dado libertad a sus hijas, Bernalda Alba sabiendo que se refiere a un pretendiente que tuvo Martirio y no fue aceptado por Bernalda, la réplica: "... Y si no lo olvida, peor para ella" (68). Es decir, no pretendió respetar los deseos de Martirio sino dominarlos.

Para Bernalda el sino existe: "Las cosas no son nunca a gusto nuestro" (69). Las cosas, por tanto, tienen un esquema propio que es desconocido a los hombres.

Bernalda afirma continuamente su dominio sobre sus hijas, hasta el punto de que en caso de que no le fueran sumisas está dispuesta a dominarlas por la fuerza (ver página 1.501). Nunca Bernalda a lo largo de toda la obra tendrá en cuenta los deseos de los que la rodean, todo lo decidirá ella "per se".

(64) Op. cit., pág. 1.485 .

(65) Op. cit., pág. 1.488 .

(66) Op. cit., pág. 1.492 .

(67) Op. cit. pág. 1.495.

(68) Op. cit., pág. 1.499.

(69) Op. cit., pág. 1.500. 
Ante el incidente de la muchacha del pueblo que ha tenido un hijo y lo ha abandonado (estaba soltera) Bernalda se muestra durísima y carece de la más mínima caridad humana. Para ella la decencia la forjan las normas del orden social, que ven mal el acto reseñado, lo demás no le importa.

Más adelante Bernalda hace una afirmación que nos demuestra más, si cabe, sus convicciones acerca de las cosas: "Una hija que desobedece deja de ser hija para convertirse en enemiga" (70). Es decir, para ella las hijas están para obedecer y para eso las creo la naturaleza. Con ésto nos indica indirectamente cuáles son los requisitos de sus hijas.

En la escena en que Bernalda habla con una tal Prudencia, demuestra reconocer las necesidades sexuales de los animales pero sin embargo, no reconoce las de sus hijas, por lo que a ella respecta sus hij as no tienen ninguna necesidad de satisfacer. La contradicción es aquí evidente. Prudencia comparará el comportamiento del caballo con el de los hombres: "Bregando como un hombre" (71), así se ponen en relación de manera tajante las necesidades corporales de los animales y de los hombres, no por ello Bernalda cambiará de actitud ante sus hijas. El caballo (animal al que se está refiriendo) es una imagen muy interesante de la que hablaremos más adelante.

García Lorca recurre a la superstición popular para dejar traslucir el destino (página 1.510). La conversación que se entabla con motivo de enseñar Angustias a Prudencia su anillo de pedida es muy significativa respecto a las distintas opiniones que tienen los personajes acerca de las tradiciones y supersticiones antecedentes del destino.

Nuevamente encontramos casi al final del último acto una referencia al determinismo natural cuando Poncia dice: "Bernarda cree que nadie puede con ella y no sabe la fuerza que tiene un hombre entre mujeres" (72). Con ello la criada alude igualmente al gran poder que puede tener el impulso sexual entre un grupo de mujeres reprimidas, como el que constituyen las hij as de Bernalda.

Un poco después Poncia también afirma: "Las cosas se han puesto ya demasiado maduras" (73). O sea, el sino no puede detenerse, las cosas han llegado muy lejos. Poncia justifica la inquietud y la desazón de las hijas de Bernalda ante la presencia de Pepe el Romano porque son "mujeres sin hombre" y en estas cosas "se olvida hasta la sangre".

Nuevamente aparece en escena la madre de Bernalda, María Josefa, y continúa su análisis sobre sus nietas.

(70) Op. cit., pág. 1.507 .

(71) Op. cit., pág. 1.509 .

(72) Op. cit., pág. 1.520.

(73) Op. cit., pág. 1.521. 
Hay que señalar que aunque María Josefa está loca, a veces percibe los acontecimientos con gran clarividencia, afirma: "Pepe el Romano es un gigante. Todas lo queréis. Pero él os va a devorar a todas porque vosotras sois granos de trigo. No granos de trigo. ¡Ranas sin lengua!" (74). Con otras palabras podemos decir que María Josefa considera a sus nietas como personas sin libertad para decidir en sus acciones o cumplir sus deseos. Además de como gigante, María Josefa definirá a Pepe como león jadeante, como representación animada del impulso sexual que devora a Adela y a él mismo.

La guerra que había presagiado Poncia se desencadena. Primero entre Adela y Martirio, esta lucha constante que se plantea entre todas las ocupantes de la casa no cesará ya hasta el fin de la obra. El motivo de la disputa es, naturalmente, Pepe el Romano. Adela se nos presenta como muy agresiva señalando la falta de voluntad y resignación de Martirio.

Cuando Adela insiste en que Pepe el Romano quiere a ella y no a Angustias, y que si corteja a ésta es por razón de dinero (debemos recordar aquí que Angustias era hija de distinto padre que el resto de las hijas de Bernalda Alba, de su primer marido que le había legado una estimable herencia). Entonces Martirio estalla y afirma que ella también lo quiere. Ante esta disputa por el mismo hombre olvidarán sus lazos de sangre porque el sexo arde en su interior y domina sobre todos sus demás condicionantes: "La que tenga que ahogarse que se ahogue" (75). Es el reto de Adela. Después ella misma afirma que una vez probado el placer con Pepe no puede resistirse a perderlo o a seguir las condiciones que pone su casa, su madre. El contacto sexual con Pepe se ha convertido en la auténtica ambición de su existencia. No le importará sufrir el castigo que se derive de la violación del código moral y social, con tal de saciar su instinto irrefrenable. Pero Martirio responde: "Eso no pasará mientras yo tenga una gota de sangre en el cuerpo" (76).

Cuando están las dos hermanas peleándose entra Bernalda. Martirio le anuncia que Adela ha estado con Pepe el Romano en el pajar ("Cama de las mal nacidas" (77), según Bernalda). Según lo que hemos indicado entre paréntesis sólo habiendo nacido mala Adela ha podido obrar como lo ha hecho, por tanto necesariamente está llena de maldad según los argumentos de Bernalda. En esta escena del final la rebelión de Adela se hace total y ostensible: "No de usted un paso más. En mí no manda nadie más que Pepe" (78). Pero con esta última afirmación Adela no pregona su independencia

(74) Op. cit., pág. 1.525.

(75) Op. cit., pág. 1.528 .

(76) Op. cit., pág. 1.528.

(77) Op. cit., pág. 1.529.

(78) Op. cit., pág. 1.529. 
completa, sino que más bien se limita a proclamar lo que es el motor de sus acciones. En resumen, el determinismo biológico (instinto sexual) sirve al destino. Adela vuelve a comparar a Pepe con un león jadeante, sin ningún tipo de delicadeza o consideración con Angustias (la prometida de Pepe). Pero el sexo no puede triunfar, y por ello se explica la afirmación de Angustias: "De aquí no sales tú con tu cuerpo en triunfo" (79). El cuerpo, pues, no triunfará.

Bernalda apunta con una escopeta a Pepe el Romano, Adela cree que lo ha matado y se ahorca. Martirio es la que le dice que ha muerto Pepe, mintiéndole. La obra de esta manera termina en luto. La obra se ha desarrollado entre violencia reprimida y ha terminado con violencia expresa. Adela pese a conocer el castigo que se le aplicará por no respetar el código social actúa como le dictan sus impulsos.

La idiosincrasia de Bernalda Alba, verdadera llave maestra de todo lo que ocurre en la obra, se resumen en la frase que cierra el drama: "... Ella, la hija menor de Bernalda Alba ha muerto virgen" (80). El código moral es lo que importa, aunque sea falseado.

Todo el destino que se dejó intuir a lo largo de la obra se ha cumplido: las hijas han quedado solteras, la tormenta ha terminado en tragedia, etc...

\section{CONCLUSIONES}

Las principales conclusiones que podemos sacar de esta lectura son a grandes rasgos:

1.-Interconexión entre libre albedrío, determinismo y su funcionamiento acorde con unos esquemas de fuerza e intensidad alternándose.

2.-Fuerza suprema del sino.

3.-Gran importancia del impulso sexual.

4.-Importancia meridiana del orden social.

5.-El reconocimiento de Bernalda Alba de todos sus esquemas al decir que su hija menor ha muerto virgen.

(79) Op. cit., pág. 1.530.

(80) Op. cit., pág. 1.532 . 